\title{
Is molecular allergology cost-effective and cost saving in children with suspected peanut allergy compared to double blind placebo controlled food challenge (DBPCFC), open oral food challenge and skin prick test in Sweden?
}

S Glaumann ${ }^{1 *}$, L-L Hermansson², B Mascialino², G Hubben ${ }^{3}$, MP Borres ${ }^{2,4}$, C Nilsson ${ }^{1}$

From Food Allergy and Anaphylaxis Meeting (FAAM 2013)

Nice, France. 7-9 February 2013

\section{Background}

Peanuts are one of the most common foods causing allergic reactions in children. IgE-ab sensitization to peanut has been reported in $7-11 \%$ of children in Western countries and the prevalence of peanut allergy (PA) in children varies between $0.75 \%$ and $3 \%$. Given the PA impact on quality-of-life (QoL), accurate diagnosis is crucial because many sensitized individuals are actually tolerant to peanut. Peanut sensitization established by IgE antibodies (IgE-ab) in blood or skin prick test (SPT) often needs to be confirmed by the "gold standard" Doubleblind placebo-controlled food challenge (DBPCFC), a risky and expensive procedure. In clinical practice an open oral food challenge (OC) is performed instead of a DBPCFC. PA can be effectively diagnosed using molecular allergology (MA), identifying subjects at risk for PA reactions (IgE-ab to Ara h 1-2-3). No cost-effectiveness (CE) analyses are available on MA for allergy.

\section{Methods}

Three 5-year Markov models simulate the flow of 200 children PA suspected presenting to the general practitioner. The models compare different diagnostic approaches (DBPCFC, OC, SPT and MA), computing the cost-perQALY (Quality Adjusted Life Year) gained based on data from the literature. Calculations were performed for

'Department of Clinical Science and Education, Södersjukhuset, Karolinska Institutet, Stockholm, Sweden

Full list of author information is available at the end of the article
Sweden and BaseCase ${ }^{\circledR}$ was used to present results. Care giver indirect costs are included in a sensitivity analysis.

\section{Results}

In Sweden, cost-per-QALY is 3.66 for SPT, 3.22 for DBPCFC, 2.23 for OC and 4.34 for MA. The cost for different diagnostic approaches is:

- SPT: 44851 SEK

- DBPCFC: 24278 SEK

- OC: 33031SEK

- MA: 11267 SEK

\section{Conclusion}

In Sweden, MA increases QoL, and it is associated with reduced costs per patient with respect to the other strategies. The hypothesized usage of MA could be a valid alternative and a useful diagnostic tool replacing the "gold standard" DBPCFC in selected cases, DBPCFC still being useful in subjects with conflicting immunological/clinical results.

\section{Disclosure of interest}

S Glaumann: None declared, L-L Hermansson: Employee of Thermo Fisher Scientific, B Mascialino: Employee of Thermo Fisher Scientific, G Hubben: Employee of BaseCase Software, M Borres: Employee of Thermo Fisher Scientific, C Nilsson: None declared.

\section{Author details}

'Department of Clinical Science and Education, Södersjukhuset, Karolinska Institutet, Stockholm, Sweden. ${ }^{2}$ Thermo Fisher Scientific, Uppsala, Sweden. 
${ }^{3}$ BaseCase Software, Berlin, Germany. ${ }^{4}$ Department of Paediatrics, Sahlgrenska Academy of Gothenburg University, Gothenburg, Sweden.

Published: 25 July 2013

doi:10.1186/2045-7022-3-S3-P124

Cite this article as: Glaumann et al:: Is molecular allergology cost-

effective and cost saving in children with suspected peanut allergy compared to double blind placebo controlled food challenge (DBPCFC) open oral food challenge and skin prick test in Sweden? Clinical and Translational Allergy 2013 3(Suppl 3):P124.

Submit your next manuscript to BioMed Central and take full advantage of:

- Convenient online submission

- Thorough peer review

- No space constraints or color figure charges

- Immediate publication on acceptance

- Inclusion in PubMed, CAS, Scopus and Google Scholar

- Research which is freely available for redistribution

Submit your manuscript at www.biomedcentral.com/submit
Ciomed Central 